UDK: 004.4.057.8:35(497.6)

Izvorni znanstveni članak

Primljen 9. X. 2019.

Mario Pezer - Marko Odak

Mostar - Filozofski fakultet Sveučilišta u Mostaru

pezer.mario@gmail.com - marko.odak@ff.sum.ba

\title{
SLOBODNI SOFTVER U JAVNOJ ADMINISTRACIJI BOSNE I HERCEGOVINE
}

\section{Sažetak}

Mnoštvo je dokazanih prednosti i koristi slobodnoga softvera (FLOSS) kao što su: bolja sigurnost i pouzdanost, smanjenje ovisnosti o dobavljačima, kontrola rukovanja osjetljivim podatcima itd. Uvidjevši to, EU pokušava potaknuti korištenje FLOSS-a u svojoj administraciji, koji je postao vrlo popularan u javnome sektoru država EU-a u posljednjih petnaestak godina. Njegova pak zastupljenost u jugoistočnoj Europi gotovo da i ne postoji. Fokus je ovoga rada istražiti korištenje FLOSS-a u javnoj upravi u Bosni i Hercegovini, odnosno ispitati zastupljenost FLOSS-a u odnosu na vlasnički softver $\mathrm{u}$ informacijskome sustavu gradova i općina u Bosni i Hercegovini. Nadalje, u radu su predstavljene i smjernice za mogući prijelaz na FLOSS te se raspravlja o glavnim prednostima primjene FLOSS-a u javnoj upravi.

Ključne riječi: Open Source softver; javna uprava; prednosti; migracija; informacijska znanost

\section{Uvod}

U posljednjih petnaest godina slobodni softver (free/libre and open source software - FLOSS) ostvario je važnu poziciju na tržištu te se nametnuo kao ozbiljna alternativa komercijalnomu softveru. Kao njegove 
glavne prednosti najčešće se spominju pouzdanost, sigurnost i niski troškovi uporabe. Svojom filozofijom i praktičnom slobodom FLOSS ne može biti ekskluzivno vlasništvo jednoga pojedinca ili izdavača te je najčešće dostupan bez troškova licencije.

Nakon krize krajem 2008. godine mnoge su vlade uvidjele da vlasnički softver nije jedini izbor te se sve više okreću alternativama u slobodnome softveru. U skladu s navedenim, sve više zemalja usvaja politike i strategije prelaska na slobodni softver u državnoj administraciji. Unatoč dokazanim prednostima FLOSS-a i dalje dominira uporaba vlasničkoga softvera. Nadalje, ne postoje šira istraživanja koja bi utvrdila razinu primjene slobodnoga softvera $u$ javnoj administraciji Bosne i Hercegovine, ali ni susjednih zemalja, a posebice nije istražena primjena slobodnoga softvera $u$ informacijskim sustavima u gradovima i općinama.

Ovim istraživanjem nastoje se sistematizirati postojeća znanja i istraživanja o slobodnome softveru te dati njegov širi pregled i razumijevanje, a osobito njegove primjene $\mathrm{u}$ javnome sektoru. Temeljni su ciljevi istraživanja:

- istražiti prednosti i nedostatke uporabe slobodnoga softvera u javnoj upravi

- istražiti zastupljenost slobodnoga softvera u lokalnoj samoupravi $\mathrm{u} \mathrm{BiH}$, odnosno vlasničkoga softvera u općinama i gradovima u $\mathrm{BiH}$, te procijeniti mogućnosti zamjene komercijalnoga softvera odgovarajućim FLOSS-ovim alternativama

- dati smjernice za lakšu migraciju na slobodni softver gradova i općina u Bosni i Hercegovini.

\section{Povezani radovi}

Prelazak na slobodni softver smanjuje ovisnost o dobavljačima, povećava sigurnost te potiče domaću softversku industriju (usp. Varian Shapiro, 2003, 20). Jedan od glavnih motivatora za migraciju na FLOSS jest smanjenje troškova, ali bi ga bilo pogrešno vezati samo za niže troškove. 
Studija ekonomskoga utjecaja razvoja slobodnoga softvera na inovaciju i konkurentnost u EU-u pokazuje da lagan i masovniji pristup slobodnomu softveru može promijeniti način pribavljanja softvera u organizaciji i omogućiti bitno usvajanje slobodnoga softvera u mnogim domenama (usp. Ghosh, 2006, 1-4).

Bouras i sur. (2014) navode da FLOSS dobiva sve više na važnosti i jača svoju stratešku poziciju unutar ekonomije znanja. Migracija na FLOSS tehnički je izazovna, ali njegovo uvođenje $u$ istraživačkome i razvojnome okruženju doprinosi smanjenju troškova IT infrastrukture i otvara vrata za veću skalabilnost i povećanje performansi IT sustava (usp. Frej i dr., 2015).

Projekt COSPA (2004 - 2006), koji je financirala EU, analizirao je učinke uvođenja slobodnoga softvera na produktivnost zaposlenika i upravljanje dokumentima u europskim administracijama. Kao dio toga projekta Rossi i suradnici (2006) istraživali su uvođenje Open Officea umjesto Microsoft Officea u javnu administraciju u pojedinim općinama u Italiji te su zaključili da ta migracija nije usporila produktivnost zaposlenika, odnosno ostvarene su znatne uštede u troškovima.

Jedan od najvažnijih tekućih projekata EU-a u kontekstu FLOSS-a jest Open Source Observatory and Repository (OSOR), koji je dio širega ISA projekta - Interoperability Solutions for European Public Administrations, za razdoblje 2010. - 2015. Platformi OSOR cilj je podržati i ohrabriti ponovnu uporabu javno financiranih razvojnih programa otvorenoga koda (OSS ili FLOSS) koji su posebno korisni za javne uprave u Europi (Open Source Observatory, 2010).

Unatoč dokazanim prednostima slobodnoga softvera njegova je zastupljenost $u$ informacijskim sustavima državne administracije niska, posebice u zemljama jugoistočne Europe. Potrebno je preispitati opravdanost gotovo isključive uporabe komercijalnoga softvera $u$ javnim institucijama, uključujući i arhiv, unatoč činjenici da je slobodan softver lako dostupan, funkcionalan i dokazano pouzdan u praksi (usp. Porubović-Vidović, 2013, 507).

Slobodan softver realna je alternativa komercijalnomu softveru, ali je preduvjet za veću preferenciju slobodnoga softvera njegovo upoznavanje 
tijekom formalnoga obrazovanja, pa zemlje koje su u tome segmentu napravile iskorak prema FLOSS-ovim rješenjima lakše provode njegovu implementaciju i u ostalim područjima (usp. Porubović-Vidović, 2013, 518).

Konjević (2009) je istraživala stanje IT infrastrukture u administracijama lokalnih samouprava u Vojvodini, stupanj prihvaćenosti slobodnoga softvera u tijelima lokalnih samouprava kao i razinu zadovoljstva korisnika ovim rješenjima. Rezultati istraživanja pokazali su dominaciju komercijalnoga softvera nad slobodnim softverom. IT menadžeri u javnome sektoru svjesni su FLOSS-ova koncepta i vrlo su stručni u korištenju njegovih aplikacija, ali unatoč tomu imaju poteškoća i problema pri njegovoj uporabi.

Kvalifikacija i izbor FLOSS-a, njegova nabava, ljudski faktori, pravna pitanja, uporabljivost, razvoj i podrška softvera glavna su pitanja i izazovi koje organizacije moraju uzeti u obzir pri izradi IT strategija i politika. Ovi izazovi služe kao prepreka organizacijama u nastojanju da uklope FLOSS-ovu tehnologiju u svojim informacijskim sustavima (usp. Quiroz Canlas - Ferddie, 2019, 17).

\section{Slobodni softver - osnovni pojmovi}

Najjednostavnije rečeno, slobodni softver je onaj softver koji se može koristiti, proučavati, unaprjeđivati, mijenjati, ponovno koristiti i dijeliti s bilo kim, bez dodatnih dopuštenja ili zakonskih regulativa. No, to ne znači nužno da je softver besplatan (iako on to najčešće i jest), već se pod pojmom "slobodno“ podrazumijeva da korisnik može s njim raditi što god želi, ali ta ista prava mora proslijediti korisnicima koji će od njega dobiti ili kupiti taj softver. Upravo ova obveza predstavlja temeljnu razliku između besplatnoga i slobodnoga softvera.

Richard M. Stallman (Free Software Foundation) definirao je četiri osnovne slobode koje se odnose na uporabu slobodnoga softvera:

- Sloboda pokretanja softvera za bilo koju svrhu. 
- Sloboda proučavanja načina rada programa, što znači i slobodu da ga korisnik prilagodi svojim potrebama. Preduvjet tomu jest prestup izvornomu kodu.

- Slobodna redistribucija kopija drugim korisnicima.

- Sloboda unaprjeđenja softvera i puštanje ovih poboljšanja u javnost kako bi se ostvarila korist za cijelu zajednicu. Pristup izvornomu kodu preduvjet je i za ovu slobodu.

U terminološkome smislu postoji više naziva za slobodni softver, npr. free software, open source software, softver otvorenoga koda, OSS, FLOSS itd. U ovome radu koristit će se ponajviše nazivi slobodni softver i FLOSS, a pod tim podrazumijeva se free i open source softver. Ipak, važno je naglasiti da postoje i određene razlike između free i open source softvera.

Cijeli softver koji je licenciran po licencijama koje su u skladu s filozofijom slobodnoga softvera ujedno je i u skladu s filozofijom softvera otvorenoga koda. Obrnuto ne vrijedi potpuno jer postoje licencije koje su u skladu s otvorenim softverom, ali nisu u skladu s filozofijom slobodnoga softvera. Komercijalni sektor koristi pojam otvoreni kod (engl. Open source) jer se on očito više povezuje s boljim modelom razvoja softvera, a time i većim profitom (na što se sve, na kraju, i svodi).

Slobodni softver (free/open source software) razlikuje se od komercijalnoga najviše po dostupnosti izvornoga koda te po tome što za najveći dio slobodnoga softvera nije potrebno plaćati naknadu za licencije. Međutim, neslobodni softver jednako tako može biti i besplatan (tzv. freeware). Freeware je softver koji je u potpunosti funkcionalan i nitko ne traži novčanu naknadu za njegovu uporabu, ali je zaštićen licencijom i izvorni kod nije dostupan korisniku.

\section{Prednosti i nedostatci uporabe slobodnoga softvera u javnoj upravi}

Primjena FLOSS-a ima niz dokazanih prednosti, ali činjenica da su neke migracije bile neuspješne ukazuje i na određene slabosti. U ovome 
poglavlju opisane su sve prednosti i nedostatci migracija na FLOSS, odnosno njegova korištenja u javnoj upravi.

\subsection{Prednosti FLOSS-a}

Kao najvažnije prednosti FLOSS-a spominju se uštede i niži troškovi, međutim pogrešno je korisnosti slobodnoga softvera vezati isključivo za uštede jer primjena slobodnoga softvera u javnome sektoru ima dublje i višestruke prednosti. U nastavku je dan pregled najvažnijih prednosti korištenja slobodnoga softvera u javnome sektoru.

Pristup izvornomu kodu temeljna je prednost FLOSS-a koja omogućuje korisnicima pregled izvornoga koda i njegovu izmjenu, prilagodbu i dogradnju. Korisnik ima mogućnost unaprijediti softver i prilagoditi ga svojim potrebama bez dopuštenja vlasnika licencije. Dokazana stabilnost FLOSS-a, primarno Linux operacijskih sustava, jedna je od njegovih prepoznatljivih prednosti koja je dokazana u više studija. IBM objavio je da provedeni stres-test pokazuje da je Linux kernel s pripadajućim komponentama operativnoga sustava stabilan i pouzdan te korisniku može osigurati pouzdanost u visokozahtjevnome okruženju tijekom dužega razdoblja (usp. Cybersource, 2004).

Linux operacijski sustavi sigurniji su jer većina zlonamjernoga softvera (virusi, crvi itd.) ne cilja Linux i slobodni softver, već su pisani tako da prouzroče štetu Windowsovim korisnicima jer će na taj način izazvati i veću ukupnu štetu. Postoji oko 60.000 poznatih virusa koji napadaju Windowsov sustav, oko 40 ih je namijenjeno Macintosh računalima, oko 5 za komercijalne verzije Unix sustava i oko 40 za Linux. Većina Windowsovih virusa nije bitna, ali njih nekoliko stotina uzrokuje štetu šireći se među računalima. S druge strane, nijedan Unix ili Linux virus nije se uspio proširiti na druga računala (usp. Peeling- Satchell, 2001, 21).

Zbog moguće ugroze nacionalne sigurnosti mnoge zemlje (primjerice Kina, Rusija i u određenoj mjeri Njemačka) odlučile su se uvođenje sustava temeljenih na otvorenome kodu u javnome sektoru. Zabrinutost za sigurnost bila je glavni motiv za donošenje odluke njemačkoga parlamenta pri uvođenju Microsoft Windows XP na radne stanice. U 
konačnici je Microsoft dopustio uvid u izvorni kod odabranoj skupini njemačkih stručnjaka. U svojoj rezoluciji Deutschlands Wirtschaft in der Informationsgesellschaft (hrv. Njemačka ekonomija u informacijskome društvu) njemački parlament naglasio je ulogu softvera otvorenoga koda po pitanju sigurnosti (usp. Deutscher Bundestag, 2002, 4 - 5). Rusija je još 2011. godine najavila okretanje softveru otvorenoga koda zbog želje da se smanji ovisnost o inozemnim proizvođačima komercijalnoga licenciranog softvera i zbog nacionalne sigurnosti (usp. Porubović - Vidović, 2013, 512).

FLOSS omogućuje smanjenje ovisnosti o dobavljačima jer je poseban problem kada proizvođač prestane s aktivnom podrškom za navedeni proizvod (primjerice, zbog nove, zamjenske verzije softvera), što za korisnika znači da mora kupiti novi softver od navedenoga proizvođača, iako postojeći softver u potpunosti zadovoljava korisnikove potrebe. Otvoreni standardi daju korisniku fleksibilnost i slobodu izbora između različitih softverskih paketa, platformi i dobavljača jer korisnik nije prinuđen pratiti razvojni ciklus i prodajne planove proizvođača, već sam odlučuje o tome kada će mijenjati ili unaprijediti svoj softver.

FLOSS ima pozitivan učinak na razvoj lokalne industrije, a posebno IT industrije. Većina vlasničkih softvera razvijena je u tvrtkama koje potječu iz maloga broja visokorazvijenih zemalja, stoga ogromna sredstva od plaćanja licencija odlaze iz manje razvijenih zemalja u te visokorazvijene zemlje. Nasuprot tomu, primjenom servisno orijentiranoga modela slobodnoga softvera troškovi su koncentrirani unutar lokalne ekonomije umjesto da su sredstva isplaćena nekoj inozemnoj multinacionalnoj kompaniji. Ovo ima pozitivan učinak na zapošljavanje, lokalnu investicijsku bazu, prihod od poreza itd.

Ukupni troškovi vlasništva slobodnoga softvera u odnosu na vlasnički softver (Total Cost of Ownership - $\mathrm{TCO}^{1}$ ) znatno su niži, što potvrđuje i više provedenih studija. Cybersourceova studija (2004.) utvrdila je

Total Cost of Ownership (TCO) - Ukupni trošak vlasništva (TCO) financijska je procjena namijenjena kao pomoć kupcima i vlasnicima za utvrđivanje izravnih i neizravnih troškova proizvoda ili sustava. To je računovodstveni koncept upravljanja koji se može koristiti za potpuni obračun troškova ili čak za ekološke ekonomije gdje uključuje i socijalne troškove. 
da moguće smanjiti TCO za $19 \%$ do 36 \% korištenjem Linuxa i FLOSS-a umjesto Microsoftova softvera. Cybersource $(2004,5)$ navodi da je korištenjem Linuxa moguće smanjiti TCO za $36 \%$ u odnosu na korištenje Windowsova softvera. Navedene uštede temelje se na mogućem smanjenju troškova licencija kod operativnih sustava i uredskoga paketa, nepotrebnih nadogradnji softvera koje su inicirali proizvođači, broja sigurnosnih nadogradnji, troškova antivirusnoga softvera (jer Linux ne treba isti) te broja osoblja koje održava sustav.

Više je znanstvenih i stručnih radova koji dokazuju korelaciju između slobodnoga softvera i povećanja inovativnosti. U knjizi Innovation Happens Elswhere: Open Source as Business Strategy Goldman i Gabriel (2005.) ističu i pojašnjavaju pozitivan utjecaj slobodnoga softvera na inovativnost. Prema Joachimu Henkelu s Instituta za inovativna istraživanja Sveučilišta u Münchenu, proizvod temeljen na otvorenome kodu može dovesti do veće kvalitete proizvoda i ostvariti veći profit nego vlasnički softver. (usp. Henkel, 20o6, 13 - 16)

Poticanjem šire uporabe FLOSS-a može se smanjiti stopa nelicenciranoga softvera u zemlji i olakšati pritisak na zemlje u razvoju s obzirom na potrebu poštivanja međunarodnih obveza na temelju prava intelektualnoga vlasništva. Dostupnost izvornoga koda kod slobodnoga softvera i mogućnost izmjene istoga pruža znatno veću fleksibilnost za prilagođavanje softverskih mogućnosti i značajki specifičnim potrebama korisnika.

\subsection{Nedostatci}

Unatoč brojnim prednostima FLOSS ima i nekoliko nedostataka koje je nužno razmotriti prilikom razmatranja mogućnosti prelaska na nj. Neke od spomenutih nedostataka moguće je izbjeći postojanjem stručnoga i kvalitetnoga lokalnog informatičkog kadra, dobrim planiranjem i/ili edukacijom korisnika. Kao najznačajniji nedostatci izdvajaju se:

a) FLOSS zahtijeva postojanje stručnoga osoblja

b) često nije user-friendly kao komercijalne verzije

c) manja podrška korisnicima u odnosu na vlasnički softver 
d) potencijalna ranjivost na napade zlonamjernih korisnika

e) veća potreba za obukom

f) nedostatak interoperabilnosti s komercijalnim proizvodima u pojedinim slučajevima.

Za uspješan prelazak na FLOSS nužno je postojanje odgovarajućega tehničkog kadra koji se može prilagoditi FLOSS-ovim specifičnim korisničkim potrebama te osigurati učinkovit rad cjelokupnoga informacijskog sustava. To je vrlo važno kako bi se aplikacije prilagodile ostalomu softveru koji čini informacijski sustav, odnosno kako bi se osiguralo da je informacijski sustav izbalansiran, kako tehnički tako i funkcionalno. Ako na lokalnome tržištu ne postoji dovoljno stručne podrške (npr. $L i$ nuxovih administratora, programera, specijalista za FLOSS itd.), teško će se provesti proces prelaska na FLOSS. Potražnja za inozemnim stručnjacima može znatno povećati troškove migracije, čak do te mjere da je isplativije odabrati vlasnički softver nego prelaziti na FLOSS. Također, bez odgovarajuće i stalno dostupne tehničke potpore nemoguće je održavati informacijski sustav, pa tako i onaj koji se temelji na FLOSS-u.

Tvrtka koja za svoj softver ostvaruje prihod naplaćujući licencije korisnicima nastoji opravdati te troškove u očima kupca. Stoga se puno pažnje posvećuje korisničkomu sučelju te se nastoji da softver bude što lakši za korištenje, odnosno da korisnik ne treba imati posebna informatička znanja za korištenje softvera. Međutim, kako primarna uloga FLOSS-a nije stvaranje komercijalnoga proizvoda koji će se prodavati i generirati novac, može se razvijati više u skladu sa željama stručnjaka koji ga razvijaju nego s potrebama krajnjega korisnika. Iz istoga razloga korisnička sučelja FLOSS-a mogu biti manje user-friendly i ne tako jednostavna za korištenje u odnosu na njihove komercijalne alternative jer im se posvećuje manje pažnje. To ne vrijedi za cijeli FLOSS jer su mnogi od njih (LibreOffice, Mozilla Firefox i Android operativni su sustavi) nevjerojatno jednostavni za korištenje. Međutim, postoji nekoliko programa koji su nastali uglavnom vođeni željama njihovih programera i u kojima nije mnogo pažnje posvećeno korisničkomu sučelju, što ga čini 
teškim za korištenje prosječnim korisnicima koji nemaju specijalistička znanja.

U slučaju tehničkih problema ili nedostupnosti podrške korisnici FLOSS-a oslanjaju se na zajednicu korisnika od kojih očekuju odgovore, pomoć u otklanjanju zastoja ili rješavanju korisničkih problema. Oni koji favoriziraju komercijalni softver, s druge strane, mirniji su jer imaju jednu adresu na koju se mogu obratiti - to je proizvođač odnosno vlasnik softvera i krajnji korisnici imaju jasnu ideju o tome koga smatrati odgovornim ako program ne radi ispravno ili im prouzroči štetu. Kod FLOSS-a se ne može uvijek jasno detektirati krajnja odgovornost za probleme. Naime, razvili su ga brojni ljudi pa korisnici nemaju određenu osobu ili društvo u koje mogu „uprijeti prstom“.

FLOSS ima otvoreni kod što znači da postoje mnogi ljudi koji mogu identificirati pogreške i iste samostalno popraviti, ali to znači i da zlonamjerni korisnici mogu vidjeti i iskoristiti sve slabosti softvera. Mnogi ljudi imaju pristup izvornomu kodu FLOSS-a, ali nemaju svi dobre namjere. Dok mnogi koriste otvorenost koda kako bi uočili nedostatke i unaprijedili rad programa, drugi pak koriste tu povlasticu kako bi istražili moguće ranjivosti proizvoda i stvaranje grešaka koje mogu zaraziti hardver, ukrasti identitet i podatke korisnika ili pak samo smetati drugim korisnicima. Međutim, zatvorenost koda nije garancija da ga zlonamjerni hakeri neće probiti i prouzročiti štetu korisnicima. Ako proizvođač ne uoči proboj koda ili nema informaciju od krajnjih korisnika, zlonamjerni hakeri mogu imati dovoljno vremena napraviti štetu dok propust ne bude uočen. S druge strane, FLOSS ima jako raširenu zajednicu programera i korisnika koji puno brže uočavaju sigurnosne propuste i isto tako brže reagiraju nego proizvođači vlasničkoga softvera. Zbog dominacije vlasničkoga softvera korisnici su „naviknuti“ na korištenje i rad u komercijalnome softveru te im je FLOSS često nepoznat i potrebna je dodatna obuka korisnika prilikom prelaska na nj.

U pojedinim slučajevima može se pojaviti nedostatak interoperabilnosti s vlasničkim softverom jer proizvođači vlasničkoga softvera ne daju na uvid pristup kodu svoga softvera i interfejs datotekama jer interoperabilnost odgovara njihovoj poslovnoj politici. 


\section{Slobodni softver u Europskoj uniji}

Zastupljenost slobodnoga softvera u javnome sektoru u svijetu, a posebno u zemljama EU-a, bitno je porasla u posljednjih petnaestak godina. Unatoč tomu dosadašnja praksa pokazuje apsolutnu dominantnost velikih proizvođača softvera, pa se to odražava na cijenu i korištenje vlasničkih standarda koji se lako proglašavaju de facto standardom. Sve to može predstavljati ozbiljan problem pri osiguranju trajne dostupnosti elektroničkih zapisa, a istovremeno utječe na to da se u budućim nabavkama softvera daje prednost istomu proizvođaču (usp. Porubović - Vidović, 2013, 510).

Većina zemalja EU-a upoznata je sa slobodnim softverom, njegovim prednostima i nedostatcima. Ipak, postoji bitna razlika u pristupima $u$ vezi s primjenom FLOSS-a u javnome sektoru. U jednome broju zemalja (npr. Francuska, Španjolska, Njemačka) postoji jaka politička potpora uvođenju slobodnoga softvera, dok neke zemlje tek počinju razmišljati o tome. Treća skupina zemalja je ona s izrazitom dominacijom vlasničkoga softvera i to su većinom manje razvijene zemlje EU-a. U zemljama jugoistočne Europe mala je primjena slobodnoga softvera, iako se neke od zemalja (npr. Hrvatska i Crna Gora) deklarativno zalažu i za primjenu slobodnoga softvera.

„Razlike prisutnosti FLOSS rešenja u različitim regijama iste države rezultat su nepostojanja prave državne strategije u pogledu FLOSS rešenja, pa o izboru softvera koji će se koristiti državne institucije odlučuju samostalno." (Porubović - Vidović, 2013, 511)

EU aktivno podupire veću primjenu slobodnoga softvera $u$ javnome sektoru te je usvojila odgovarajuću strategiju korištenja FLOSS-a. Strategija Europske komisije za unutarnje korištenje softvera otvorenoga koda (Open Source Strategy in the European Commission, 20oo) prvi je put usvojena 20oo. godine i od tada se redovito ažurira. Korištenje FLOSS-a Europska komisija povećava i proširuje na nova područja sa svakom novom verzijom. U Strategiji za razdoblje 2014. - 2017. navedeno je da će Europska komisija, koja već koristi FLOSS za mnoge od njegovih glavnih ICT usluga i softverskih rješenja, dodatno interno 
povećati ulogu ove vrste softvera. Strategija stavlja poseban naglasak na nabavu, doprinos za projekte razvoja softvera otvorenoga koda te osiguravanje više FLOSS-ova razvijenih unutar Europske komisije.

Open Source Observatory and Repository projektu cilj je podržati zajednički razvoj OSS aplikacija i rješenja, posebno prekograničnu suradnju i razmjenu znanja ili softvera.

Misija OSOR-a jest postati pouzdan opservatorij koji pruža FLOSSove ekspertize i informacije, a služi i kao središte za povezivanje europske javne uprave s drugim relevantnim dionicima. Kako bi postigao taj cilj, OSOR će podržati dinamičnu zajednicu i dalje promicati uporabu slobodnoga i otvorenoga koda softvera (Open Source Observatory, 2010). Pregled svih tekućih FLOSS-ovih projekata i aktivnosti u zemljama EU-a moguće je vidjeti u godišnjem izvještaju (usp. Open Source Observatory Annual Report, 2016, 4-30).

Pojedine članice EU-a imaju zakonsku regulativu koja obvezuje javnu upravu da u javnim nabavkama mora uzeti u obzir FLOSS-ove aplikacije i sustave. Primjerice, Francuska je 2012. godine usvojila dokument pod nazivom Upotreba slobodnoga softvera $u$ administraciji (Usage du logiciel libre dans l'administration, 2012) u kojem su precizirani uvjeti nabave novoga softvera koje javna institucija treba ispuniti da bi se FLOSS-ovo rješenje smatralo odgovarajućim. Početna je premisa da se pri donošenju odluke o izboru softvera u državnim tijelima ni jednome softveru ne smije dati prednost samo zato što je FLOSS, odnosno vlasnički softver. Sukladno poslovnim potrebama, prije nabave treba razmotriti oba softvera i utvrditi zadovoljava li svaki od njih tražene funkcionalnosti, kakve su im performanse, pouzdanost, potpora, dokumentacija, otvorenost koda i sl.

\section{Istraživanje}

\subsection{Metodologija}

Podatci su prikupljeni korištenjem online upitnika na reprezentativnome uzorku općina i gradova u $\mathrm{BiH}$ od veljače do srpnja 2017. godine. 
Od ukupno 144 općine/grada u Bosni i Hercegovini istraživanju se odazvalo 45 ispitanika (što iznosi $31,2 \%$ ukupne populacije). Iz Federacije $\mathrm{BiH}$ sudjelovalo je 37 (od ukupno 81 općina/gradova), dok je iz Republike Srpske istraživanju pristupilo 8 općina/gradova (od ukupno 63).

Online upitnik sa sedam pitanja dostavljen je odgovornim osobama $\mathrm{u}$ jedinicama lokalne samouprave, a pitanja su grupirana u četiri kategorije u skladu s ciljevima istraživanja: a) identificiranje osoba koje odlučuju o nabavci i izboru softverskih rješenja, b) zastupljenost komercijalnoga softvera i FLOSS-a u lokalnoj samoupravi, c) iskorištenosti alata za uredsko poslovanje, d) stavovi odgovornih osoba prema FLOSS-u.

Upitnik je sadržavao nekoliko vrsta pitanja uključujući i skaliranje primjenom skale Likertova tipa. Prvo pitanje (korišten je zatvoreni tip pitanja s ponuđenim odgovorima) usmjereno je na identificiranje odgovorne osobe o nabavci i izboru softverskih rješenja u njihovoj jedinici lokalne samouprave. Zastupljenost komercijalnoga softvera i FLOSS-a testirana je s 4 pitanja (drugo, treće, četvrto i peto pitanje), pri čemu su korišteni tzv. Single Textbox i Matrix vrste pitanja. Razina iskorištenosti alata iz uredskoga paketa u svakodnevnome radu u pogledu broja zaposlenika koji ih koriste i važnosti alata za obavljanje njihovih svakodnevnih poslova testirana je šestim pitanjem, pri čemu je primijenjena Likertova skala. Četvrta kategorija pitanja (sedmo) usmjerena je na testiranje stavova odgovornih osoba prema FLOSS-u (korištena je Likertova skala).

\subsection{Rezultati i diskusija}

Prema rezultatima, pri nabavci i izboru softvera glavnu ulogu većinom imaju načelnik/gradonačelnik $(62,2 \%)$ i zaposlenik zadužen za informatiku $(28,9 \%)$. 
Tko odlučuje o nabavci i izboru softverskih rješenja u Vašoj jedinici lokalne samouprave? (ukoliko u odluci sudjeluje više od ponuđenih i subjekata, odaberite onog

čije je uloga presudna u konačnom odabiru)

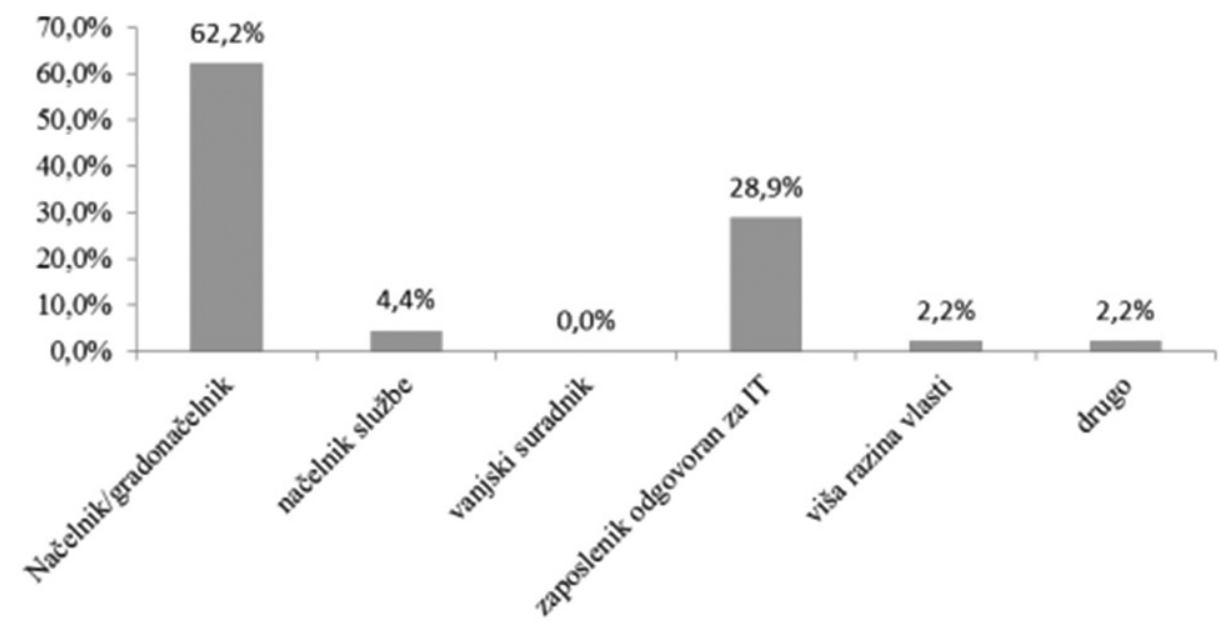

Grafikon 1. Donositelji odluka o izboru i nabavci softvera u jedinicama lokalne samouprave

U cilju provjere zastupljenosti FLOSS-a i vlasničkoga softvera na razini operativnih sustava i uredskoga paketa ispitanicima je postavljeno pitanje koliko se često u svakodnevnome radu koristi neki od ponuđenih softvera. Pri tome je korištena matrica s ponuđenim softverima $\mathrm{s}$ ponuđenom skalom učestalosti, a ispitanici su davali odgovore za svaki od ponuđenih softvera. Utvrđeno je da vlasnički softver dominira kako u dijelu operativnoga sustava tako i kod uredskoga paketa.

Analiza podataka pokazuje da su Microsoftovi operativni sustavi najzastupljeniji, kako na stolnim računalima tako i na razini servera, a slobodni softver gotovo da i nije zastupljen kao operativni sustav. Detaljni pregled odgovora vezanih za korištenje operativnih sustava sadržan je donjoj tablici: 
Tablica 1. Operativni sustavi u jedinicama lokalne samouprave

\begin{tabular}{|c|c|c|c|c|c|}
\hline & Nikako & Rijetko & Ponekad & Često & Vrlo često \\
\hline Windows XP & $4,4 \%$ & $13,3 \%$ & $17,8 \%$ & $26,7 \%$ & $28,9 \%$ \\
\hline Windows 7 & $0,0 \%$ & $4,4 \%$ & $4,4 \%$ & $48,9 \%$ & $37,8 \%$ \\
\hline Windows 8 & $17,8 \%$ & $15,6 \%$ & $24,4 \%$ & $6,7 \%$ & $2,2 \%$ \\
\hline Windows 10 & $8,9 \%$ & $20,0 \%$ & $15,6 \%$ & $35,6 \%$ & $11,1 \%$ \\
\hline Windows Server NT & $48,9 \%$ & $0,0 \%$ & $4,4 \%$ & $4,4 \%$ & $4,4 \%$ \\
\hline Windows Server 2000 & $55,6 \%$ & $2,2 \%$ & $2,2 \%$ & $2,2 \%$ & $0,0 \%$ \\
\hline Windows Server 2003 & $22,2 \%$ & $6,7 \%$ & $11,1 \%$ & $20,0 \%$ & $22,2 \%$ \\
\hline Linux Red Hat & $62,2 \%$ & $0,0 \%$ & $0,0 \%$ & $0,0 \%$ & $2,2 \%$ \\
\hline Linux Ubuntu & $57,8 \%$ & $6,7 \%$ & $0,0 \%$ & $0,0 \%$ & $0,0 \%$ \\
\hline Apache Server & $60,0 \%$ & $4,4 \%$ & $4,4 \%$ & $0,0 \%$ & $2,2 \%$ \\
\hline
\end{tabular}

Najzastupljeniji operativni sustavi na stolnim i prijenosnim računalima su: Microsoft 7, Microsoft XP i Microsoft 10. Što se tiče uporabe operativnoga sustava temeljena na otvorenome kodu, njegova je uporaba na niskoj razini i prisutna je uglavnom na razini servera:

- Apache Server - vrlo često koristi se u 2,2 \% jedinica lokalne samouprave, u njih 4,4\% koristi se ponekad, dok se u $4,4 \%$ jedinica koristi rijetko.

- Linux Red Hat - vrlo često koristi se u 2,2 \% jedinica lokalne samouprave.

Kod uredskoga paketa također dominira vlasnički softver, ali, unatoč tomu, 13,3\% ispitanika vrlo često koristi OpenOffice uredski paket, dok 6,7 \% ispitanika vrlo često koristi LibreOffice. Detaljni pregled odgovora sadržan je donjoj tablici:

Tablica 2. Zastupljenost uredskih paketa u jedinicama lokalne samouprave

Microsoft Office XP
Microsoft Office 2003
Microsoft Office 2007
Microsoft Office 2010
Microsoft Office 2013
Microsoft Office 2016
OpenOffice/Apache OpenOffice
LibreOffice
Google Docs
WPS Office 2016
Drugo

Microsoft Office XP

Microsoft Office 2003

Microsoft Office 2013

LibreOffice

WPS Office 2016

\begin{tabular}{|c|c|c|c|c|}
\hline Nikako & Rijetko & Ponekad & Često & Vrlo često \\
\hline $51,1 \%$ & $2,2 \%$ & $4,4 \%$ & $2,2 \%$ & $4,4 \%$ \\
\hline $17,8 \%$ & $17,8 \%$ & $20,0 \%$ & $\square 11,1 \%$ & $13,3 \%$ \\
\hline $6,7 \%$ & $4,4 \%$ & $17,8 \%$ & $28,9 \%$ & $28,9 \%$ \\
\hline $20,0 \%$ & $8,9 \%$ & $22,2 \%$ & $\square 15,6 \%$ & $8,9 \%$ \\
\hline $37,8 \%$ & $11,1 \%$ & $8,9 \%$ & $11,1 \%$ & $4,4 \%$ \\
\hline $53,3 \%$ & $6,7 \%$ & $2,2 \%$ & $2,2 \%$ & $2,2 \%$ \\
\hline $28,9 \%$ & $17,8 \%$ & $11,1 \%$ & $4,4 \%$ & $13,3 \%$ \\
\hline $51,1 \%$ & $0,0 \%$ & $4,4 \%$ & $2,2 \%$ & $6,7 \%$ \\
\hline $44,4 \%$ & $13,3 \%$ & $2,2 \%$ & $2,2 \%$ & $0,0 \%$ \\
\hline $60,0 \%$ & $0,0 \%$ & $0,0 \%$ & $0,0 \%$ & $2,2 \%$ \\
\hline $53,3 \%$ & $4,4 \%$ & $0,0 \%$ & $0,0 \%$ & $4,4 \%$ \\
\hline
\end{tabular}


Pored zastupljenosti FLOSS-a na razinama operativnih sustava i uredskoga paketa, istraživanjem je obuhvaćena i njegova zastupljenost kod alata za pristup elektroničkoj pošti, internetskim tražilicama te popularnost poznatih FLOSS-ovih aplikacija među korisnicima. Korišten je otvoreni tip pitanja (treće pitanje) te je ispitanicima ponuđeno navesti sve alate za pristup elektroničkoj pošti, a rezultati su navedeni u sljedećem grafikonu:

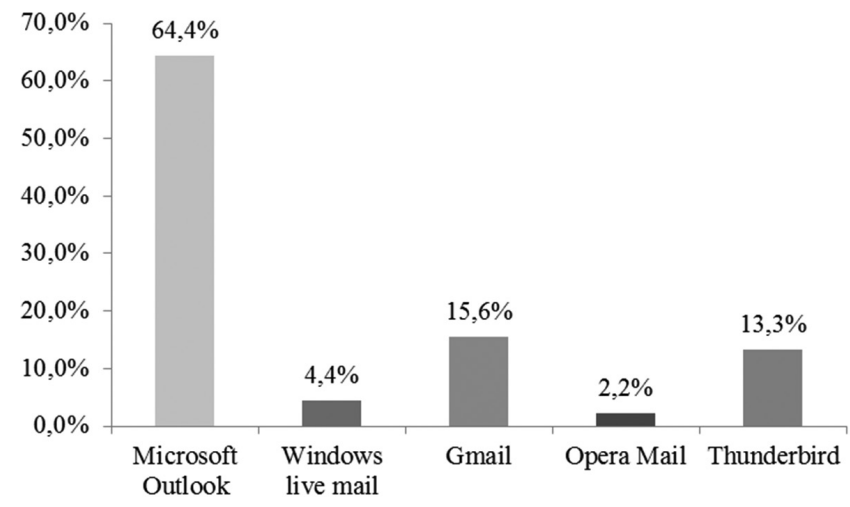

Grafikon 2.Najčěčce korišteni alati za pristup elektroničkoj pošti

Rezultati ukazuju na veću popularnost FLOSS-a među korisnicima u ovome segmentu, za razliku od operativnih sustava i uredskoga paketa. Prema rezultatima, 68,8 \% korisnika služi se Microsoftovim alatima za pristup elektroničkoj pošti, dok je Thunderbird (FLOSS-ov alat) prisutan kod 13,3 \% korisnika.

Ipak, najveća je zastupljenost FLOSS-a u lokalnoj samoupravi u dijelu internetskih tražilica. Petim pitanjem (korišten je otvoreni tip pitanja) provjereno je koji se softver najčešće koristi za pristup internetu. Dobiveni rezultati predstavljeni su u sljedećem grafikonu: 


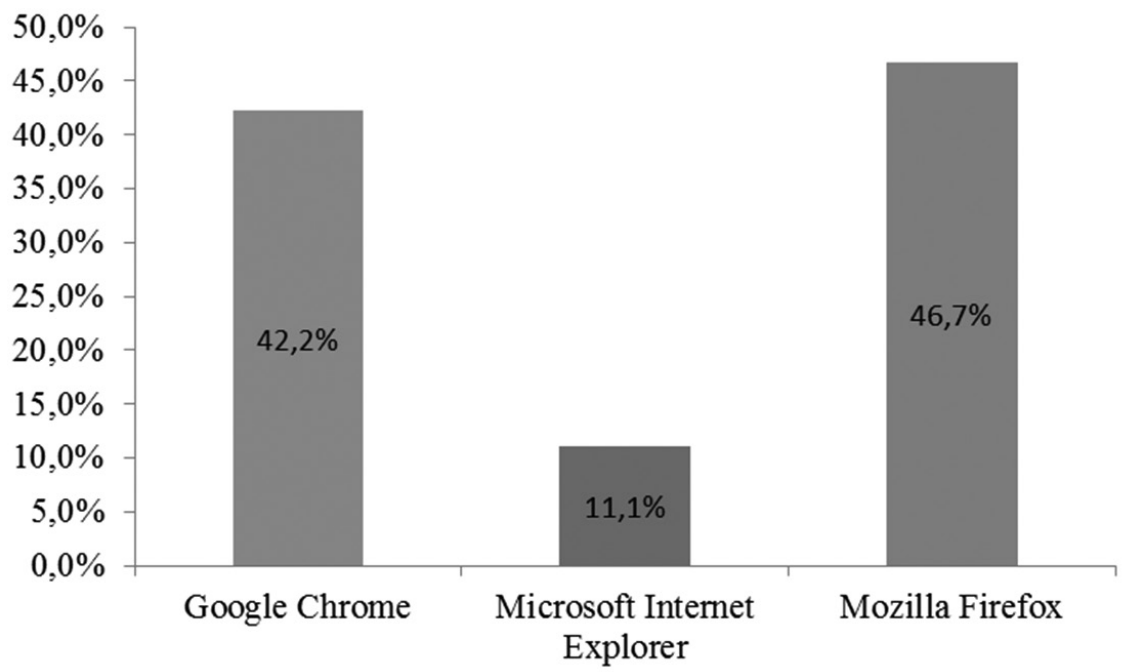

Grafikon 3. Najpopularniji alati za pristup internetu

Iznenađuje podatak da u ovoj kategoriji vlasnički softver nije dominantan, već je najpopularniji Mozilla Firefox (softver otvorenoga koda) sa 46,7 \%, dok je Googleov Chrome na drugome mjestu sa 42,2 \%, a Microsoft Explorer na trećem mjestu s 11,11 \% popularnosti.

Rezultati istraživanja potvrđuju da zaposlenici u lokalnoj samoupravi koriste samo manji dio mogućnosti uredskoga paketa, odnosno da se svakodnevno najviše koriste tekst-procesorom (89\%), alatom za pristup elektroničkoj pošti (56 \%) i tabličnim kalkulatorom (38\%). Dijelovi standardnoga uredskog paketa koji koristi tek dio zaposlenika su: alat za prezentacije ( $38 \%$ korisnika ga rijetko ili nikako ne koristi), alat za baze podataka (71\% korisnika ga rijetko ili nikako ne koristi), alat za izradu publikacija (96\% korisnika ga rijetko ili nikako ne koristi).

Detaljni rezultati istraživanja prikazani su u donjoj tablici: 


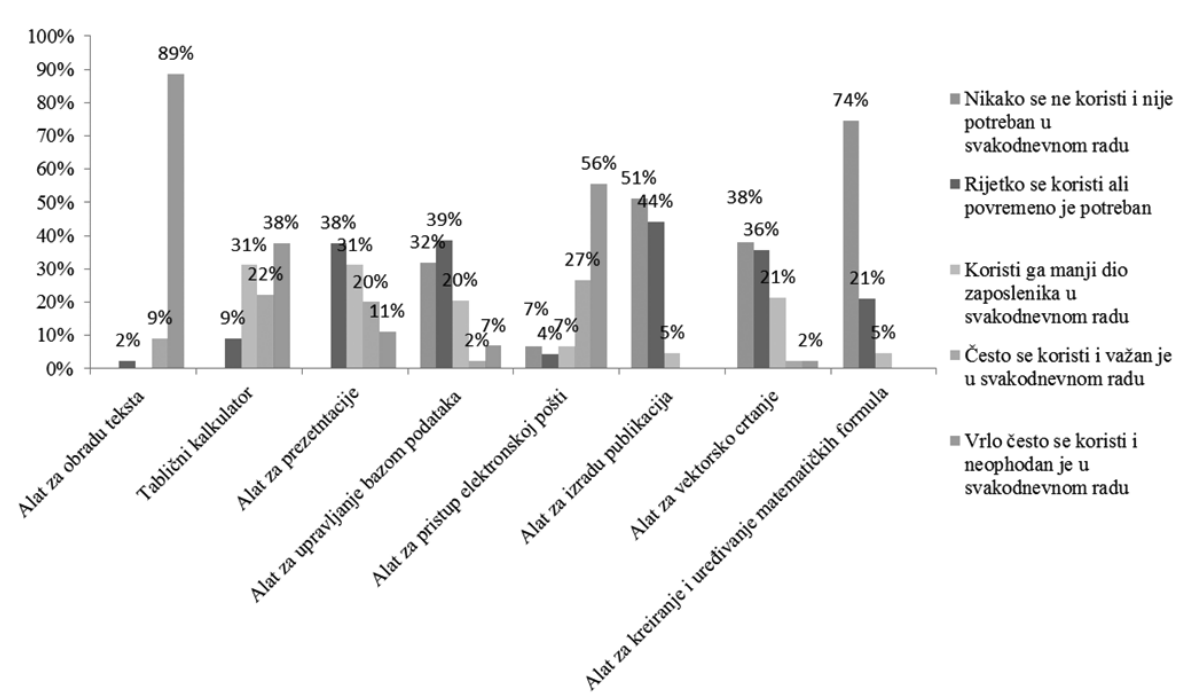

Grafikon 4. Iskorištenost i važnost alata iz uredskoga paketa za zaposlenike lokalne samouprave

Sedmim pitanjem istraženi su stavovi ispitanika prema FLOSS-u i njegovo poznavanje. Ispitanicima su ponuđene određene tvrdnje, a oni su, korištenjem Likertove skale, ocjenjivali u kojoj se mjeri slažu odnosno ne slažu s ponuđenim tvrdnjama. Rezultati su navedeni u sljedećem grafikonu:

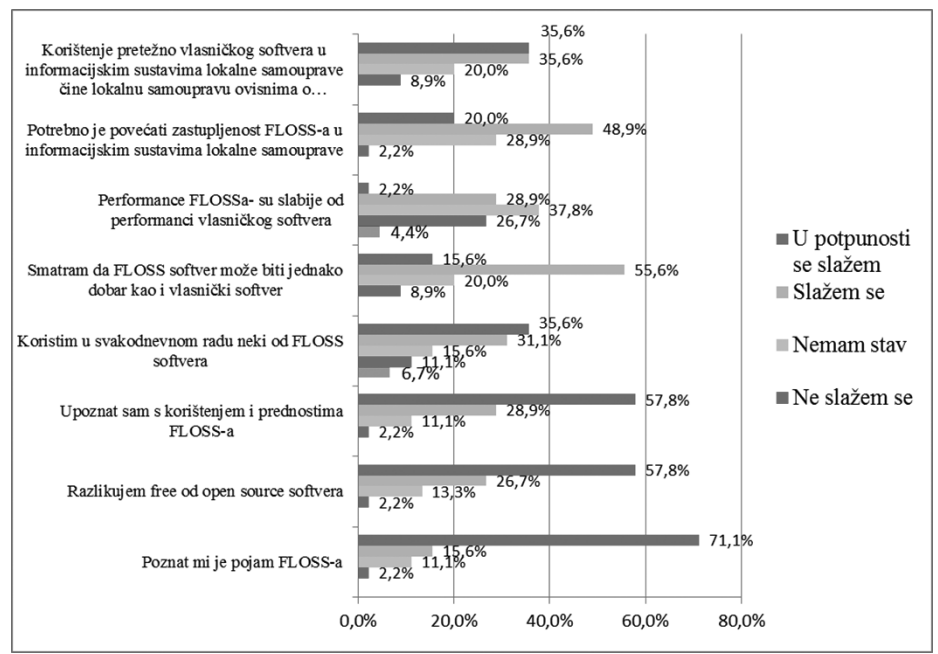

Grafikon 5. Stavovi ispitanika prema FLOSS-u 
Rezultati pokazuju da je većina ispitanika upoznata s pojmom i prednostima FLOSS-a:

- 86,7 \% ispitanika potvrdno je odgovorilo na tvrdnju „Poznat mi je pojam FLOSS-a“, od čega je 71,1 \% navelo da se u potpunosti slaže, a $15,6 \%$ da se slaže s ovom tvrdnjom

- 84,5 \% ispitanika razlikuje "free od open source softvera" (57,8 \% ispitanika se u potpunosti slaže, dok se 26,7 \% nih slaže s ovom tvrdnjom)

- $86,7 \%$ ispitanika upoznato je s korištenjem i prednostima FLOSS-a $(57,8 \%$ ispitanika se u potpunosti slaže, dok se $28,9 \%$ njih slaže s ovom tvrdnjom).

Nadalje, utvrđeno je da 71,1 \% korisnika smatra da FLOSS može biti alternativa vlasničkomu softveru $-15,6 \%$ ispitanika se $u$ potpunosti slaže s tvrdnjom da „FLOSS softver može biti jednako dobar kao i vlasnički softver", dok se s navedenom tvrdnjom slaže 55,6 \% ispitanika.

Ispitanici nisu imali jasan stav na tvrdnju „Performanse FLOSS-a su slabije od performansi vlasničkog softvera" te su odgovori prilično podijeljeni $(31,1 \%$ ispitanika slaže se s ovom tvrdnjom, a isto toliko ih se ne slaže). Također, $37,8 \%$ ispitanika nema izražen stav na ovu tvrdnju (odgovorili su: „Nemam stav“).

Unatoč pozitivnim stavovima prema FLOSS-u njegova primjena $\mathrm{u}$ praksi nešto je manja te ga u svakodnevnome radu koristi $66,7 \%$ ispitanika (35,6 \% ispitanika se u potpunosti slaže s ponuđenom tvrdnjom „Koristim u svakodnevnom radu neki od FLOSS softvera“, dok se njih $31,1 \%$ slaže s ovom tvrdnjom). Na isto pitanje 17,8 \% ispitanika odgovorilo je da ne koristi FLOSS u svakodnevnome radu, dok 15,6 \% ispitanika nije imalo stav $u$ vezi s ovim pitanjem.

Ipak, većina je ispitanika svjesna negativnih osobina korištenja vlasničkoga softvera u smislu ovisnosti o dobavljačima te smatra da je potrebno povećati zastupljenost FLOSS-a u informacijskim sustavima lokalne samouprave:

- S tvrdnjom „Korištenje pretežno vlasničkog softvera u informacijskim sustavima lokalne samouprave čini lokalnu samoupravu 
ovisnima o dobavljačima vlasničkog softvera" slaže se $71,1 \%$ ispitanika, ne slaže se $8,9 \%$ ispitanika, dok $20 \%$ njih nema stav po ovome pitanju

- Da je „potrebno povećati zastupljenost FLOSS-a u informacijskim sustavima lokalne samouprave", smatra 68,9 \% ispitanika, a 2,2 $\%$ ispitanika ne slaže se s ovom tvrdnjom, dok $28,9 \%$ ispitanika nema izgrađen stav po ovome pitanju.

\section{Smjernice za povećanje razine korištenja FLOSS-a u javnoj administraciji BIH}

S obzirom na pozitivan stav ispitanika prema većoj zastupljenosti FLOSS-a, nisku razinu iskorištenosti uredskoga softvera i korisničkih potreba te upoznatost korisnika s FLOSS-om u praksi, nužno je razmotriti argumente za zamjenu vlasničkoga softvera njegovim alternativama u vidu FLOSS-a. Više je razloga za to.

Kao prvo, u praksi je dokazano da je FLOSS moguće integrirati s postojećim vlasničkim softverom. Naime, pojedine jedinice lokalne samouprave već koriste FLOSS uredski paket na dijelu računala te nema prepreka da ta iskustva ne podijele s ostalim općinama i gradovima, odnosno da FLOSS ne postane zastupljeniji na računalima zaposlenika lokalne samouprave.

Kao drugi razlog ističu se niski korisnički zahtjevi zaposlenika lokalne samouprave te bi FLOSS mogao zadovoljiti korisničke potrebe većine korisnika uredskoga paketa. Potrebno je napraviti detaljnu analizu korisničkih potreba i, u skladu s rezultatima iste, prilagoditi dostupnost pojedinih sadržaja uredskoga paketa za različite korisnike. S obzirom na niske korisničke zahtjeve zaposlenika u lokalnoj samoupravi, FLOSS može biti korišten kao alternativa vlasničkomu softveru uredskoga paketa. Nudi dobra rješenja, primjerice LibreOffice i OpenOffice koji u potpunosti mogu zamijeniti vlasnički softver, stoga bi ih svakako trebalo uzeti u obzir kao moguću alternativu.

Treći bi razlog, naravno, bili niži IT troškovi s obzirom na to da FLOSS uredski paket ne zahtijeva plaćanje licencija, dok je četvrti razlog 
eliminacija lock in učinka, odnosno ovisnosti o jednome dobavljaču i prestanak obveza praćenja njegovih razvojnih trendova. Migracija na uredski paket otvorenoga koda (OpenOffice ili LibreOffice), pored izravnih ušteda, produljila bi vijek uporabe hardvera. Da je navedeno moguće, potvrđuje uporaba ovih alata u pojedinim općima u BiH te se ovaj softver koristi usporedno s MS Officeom. Najbolji primjer zamjene $M S$ Officea FLOSS-ovim uredskim paketom vidljiv je na primjerima provedenih migracija na LibreOffice u talijanskim gradovima i općinama.

S obzirom na rezultate istraživanja i specifičnosti, za Bosnu i Hercegovinu najprihvatljiviji je tzv. talijanski model. Ovaj model znači zamjenu MS Office paketa LibreOfficeom/OpenOfficeom uz zadržavanje Windowsova operativnog sustava u srednjoročnome razdoblju. Pri tome se mogu koristiti iskustvima talijanskih gradova, ali i drugih europskih gradova i općina u procesu migracija, a sami prelazak ne bi bio „bolan“ jer ne zahtijeva znatna visoka IT znanja, odnosno moguće je iste osigurati lokalno ili regionalno.

Aktivna podrška za Windows XP prestala je 2014., a za Windows 7 2020. godine, te je nužno zamijeniti ove operativne sustave u cilju povećanja sigurnosti i stabilnosti informacijskih sustava. U slučaju odabira nekoga od Windowsovih rješenja morala bi se izdvojiti znatna financijska sredstva za troškove licencija. U cilju ublažavanja financijskoga troška i ostvarenja mogućih ušteda, moguće je dio softvera zamijeniti FLOSS-om. U postojećoj praksi nameću se dva osnovna modela migracije na slobodni softver:

1) Potpuna migracija na slobodni softver na svim računalima na kojima je to operativno moguće podrazumijeva zamjenu operativnoga sustava (najčešće prelazak na neki od Linuxovih distribucija) te pronalazak alternative za cijeli vlasnički softver $\mathrm{u}$ vidu FLOSS-a (npr. MS Office zamjenjuje se LibreOfficeom, MS Outlook Thunderbirdom, Corel Draw Inkscapeom i sl.)

2) Djelomična migracija na slobodni softver znači da se istovremeno u informacijskome sustavu koristi i vlasnički i slobodni softver, odnosno mijenja se dio aplikacija ovisno o kvaliteti, troškovima i 
strategiji vlasnika informacijskoga sustava (primjerice, zadržava se Windows operacijski sustav, ali se zamjenjuje uredski paket na jednome dijelu računala).

Soft-migracija podrazumijeva postupnu zamjenu aplikacija vlasničkoga softvera alternativama slobodnoga softvera gdje je to operativno moguće i opravdano te privikavanje korisnika na nove aplikacije. Nakon uspješnoga prelaska na FLOSS-ove aplikacije može se (a ne mora) naknadno pristupiti zamjeni operativnoga sustava, a da to korisnici gotovo i ne osjete jer su već priviknuti na aplikacije. Osim zamjene uredskoga paketa, moguće je uvesti i druge FLOSS-ove aplikacije kojima bi se zamijenio vlasnički softver. $\mathrm{Na}$ taj način korisnici bi se priviknuli na nove aplikacije te bi bio olakšan eventualni prijelaz na Linux operativni sustav jer bi korisnička sučelja ostala gotovo nepromijenjena. Lista FLOSS-ovih aplikacija kojima je moguće zamijeniti vlasnički softver navedena je u nastavku.

Tablica 3. Pregled FLOSS-ovih aplikacija koje mogu biti alternativa vlasničkomu softveru

\begin{tabular}{|c|c|c|}
\hline Namjena softvera & FLOSS alternativa & $\begin{array}{l}\text { Vlasnički softver koji može } \\
\text { zamijeniti }\end{array}$ \\
\hline \multirow{2}{*}{ Uredski paket } & LibreOffice & \multirow{2}{*}{ Microsoft Office } \\
\hline & Apache OpenOffice & \\
\hline E-mail & Mozilla Thunderbird & Microsoft Outlook \\
\hline \multirow[t]{2}{*}{ Antivirusni softver } & $\begin{array}{l}\text { Bitdefender Antivirus Free } \\
\text { Edition }\end{array}$ & Norton AntiVirus \\
\hline & Clam WIN & McAfee \\
\hline Obrada fotografija & GIMP & Adobe Photoshop \\
\hline \multirow{4}{*}{ Media } & VLC Player & Windows Media Player \\
\hline & SMPlayer & Winamp \\
\hline & Miro & \multirow{2}{*}{ Nero } \\
\hline & $K 3 b$ & \\
\hline \multirow{2}{*}{ FTP program } & \multirow{2}{*}{ FileZilla } & WinFTP \\
\hline & & Cute FTP \\
\hline
\end{tabular}


SLOBODNI SOFTVER U JAVNOJ ADMINISTRACIJI BOSNE I HERCEGOVINE

\begin{tabular}{|c|c|c|}
\hline \multirow{3}{*}{$P D F$} & PDFCreator & \multirow{3}{*}{ Adobe Acrobat } \\
\hline & Foxit PDF Reader & \\
\hline & Evince & \\
\hline \multirow{3}{*}{ Projekt menadžment } & GanttPV & \multirow{3}{*}{ Microsoft Project } \\
\hline & Open Project & \\
\hline & Libre Plan & \\
\hline Kalendar & Lightning Calendar & $\begin{array}{l}\text { Microsoft Outlook } \\
\text { Calendar }\end{array}$ \\
\hline \multirow{2}{*}{ Grafika } & \multirow{2}{*}{ Inkscape } & Adobe Illustrator \\
\hline & & CorelDraw \\
\hline \multirow{3}{*}{ Stolno izdavaštvo } & \multirow{3}{*}{ Scribus } & PageMaker \\
\hline & & InDesign \\
\hline & & QuarkXPress \\
\hline Namjena softvera & FLOSS alternativa & $\begin{array}{l}\text { Vlasnički softver koji može } \\
\text { zamijeniti }\end{array}$ \\
\hline \multirow{4}{*}{ Baza podataka } & \multirow{2}{*}{ Base } & Access \\
\hline & & Microsoft SQL Server \\
\hline & \multirow{2}{*}{ PostgreSQL } & Oracle DB \\
\hline & & $I B M D B 2$ \\
\hline \multirow{3}{*}{ Web-tražilica } & \multirow{3}{*}{ Firefox Mozilla } & Internet Explorer/Edge \\
\hline & & Opera \\
\hline & & Google Chrome \\
\hline Uslužni & 7-Zip & WinZip \\
\hline IP telefonija & Asterisk & $\begin{array}{l}\text { Cisco Unified } \\
\text { Communications Manager }\end{array}$ \\
\hline
\end{tabular}

Sve navedene FLOSS-ove aplikacije iz prethodne tablice dostupne su i za Windowsove i za Linux operativne sustave, što javnoj upravi omogućava zamjenu komercijalnoga softvera njegovim FLOSS alternativama i bez prelaska na Linux operativni sustav. Nakon prilagodbe korisnika na nove aplikacije znatno je olakšana kasnija eventualna zamjena 
operativnoga sustava (odnosno prelazak na $\operatorname{Linux}$ ) jer ne dolazi do zamjene alata koji se svakodnevno koriste.

S obzirom na to da gotovo trećina korisnika koristi MS Office 2003, procjenjuje se da će ovim korisnicima biti lakše prijeći na LibreOffice/ OpenOffice nego na MS Office 2016 zbog slična grafičkog sučelja. Prelazak na slobodni softver u soft varijanti donio bi manji TCO za 31,9 \%, a ušteđena financijska sredstva mogla bi biti usmjerena na razvoj lokalne IT industrije, posebice u dijelu maloga i srednjega poduzetništva i razvoja (slobodnoga) softvera.

Razdoblje od 3 godine nakon implementacije verzije 2 potrebno je iskoristiti za razvoj domaćih IT kadrova u dijelu slobodnoga softvera (posebice Linuxa), koji su ključni za eventualni potpuni prelazak na slobodni softver. Prelazak na Linux u ovome trenutku nije ozbiljna alternativa zbog nedostatka tehničke potpore i znanja lokalnih informatičara o ovome softveru te zbog problema nekompatibilnosti postojećih specijaliziranih aplikacija s Linux operativnim sustavom. Također, zbog manjih hardverskih zahtjeva LibreOfficea i OpenOfficea moguće je odgoditi zamjenu jednoga broja računala u trogodišnjem ciklusu, čime bi se ostvarila dodatna ušteda.

\section{Zaključak}

Provedeno istraživanje pokazuje apsolutnu dominaciju vlasničkoga softvera u informacijskim sustavima lokalne samouprave $\mathrm{BiH}$, malu zastupljenost slobodnoga softvera, slabu iskorištenost svih mogućnosti uredskoga paketa, ali spremnost većine lokalnih IT stručnjaka za veću uporabu slobodnoga softvera. Iskustva migracija na FLOSS u zemljama Europske unije pokazuju da je, s obzirom na korisničke potrebe i zahtjeve, moguće dio komercijalnoga softvera zamijeniti odgovarajućim alternativama slobodnoga softvera uz zadržavanje iste razine učinkovitosti.

FLOSS se u lokalnoj samoupravi $\mathrm{BiH}$ najviše koristi kao internet, e-mail klijent te kao utility softver. Ipak, njegov uredski paket prepoznali su korisnici te ga dio ispitanih gradova i općina svakodnevno koristi u svome radu. Nadalje, ispitanici imaju većinom pozitivne stavove 
prema FLOSS-u i većinom smatraju da je potrebno povećati zastupljenost FLOSS-a u informacijskim sustavima lokalne samouprave. Manji dio općina i gradova u $\mathrm{BiH}$ već je zamijenio dio vlasničkoga softvera FLOSS-om, uključujući i uredski paket, te ga uspješno spojio u svoje informacijske sustave. Sve navedeno potvrđuje da je moguće dio komercijalnoga softvera zamijeniti odgovarajućim alternativama slobodnoga softvera uz zadržavanje iste razine učinkovitosti.

Dosadašnja je praksa pokazala da je potpuna migracija rijetka, a još je rjeđa uspješna potpuna migracija, te da prelazak na slobodni softver ustvari znači simbiozu vlasničkoga i slobodnoga softvera. Imajući u vidu preferencije ispitanika, postojeće trendove te iskustva zemalja Europske unije za javnu administraciju Bosne i Hercegovine, preporučuje se model tzv. soft-migracije. Stoga, pri odabiru softvera FLOSS treba uzeti kao realnu alternativu u većini radnih stanica u općinama i gradovima Bosne i Hercegovine.

\section{Literatura}

- Bouras, C., i dr. (2014) „Policy recommendations for public administrators on free and open source software usage", Telematics and Informatics, god. XxxI, br. 2, str. 237-252.

- „Linux vs. Windows total cost of ownership comparison“, (2004) Cybersource <https://static.lwn.net/images/pdf/cybersource-tco-study.pdf> (28. III. 2020.).

- "Deutschlands Wirtschaft in der Informationsgesellschaft", (2002) Deutscher Bundestag, 2. II. 2001. <http://dip.bundestag.de/ btd/14/052/1405246.pdf> (20. III. 2020.).

- Free Software Foundation, <http://fsfe.org >, (20. III. 2020.).

- Frej, Mohamed B. H. i dr., (2015) „Open Source Software: adoption and challenges" 2015 ASEE Northeast Section Conference.

- Ge, Li - Scott, Linda - VanderWiele, Mark (2003),Putting Linux reliability to the test", IBM, <http://www.ibm.com/developerworks/library/l-rel/>, (11. III. 2020.). 
- Ghosh, Rishab, A. (2006) „Study On the Economic Impact of Open Source Software on Innovation and the Competiveness of the Information and Communication Technologies (ICT) Sector in the EU", UNU-MERIT, <https://www.campussource.de/opensource/docs/FLOSSImpactOnEU.pdf >, (20. II. 2019.).

- Goldman, Ron - Gabriel, P. Richard (2005) Innovation Happens Elsewhere: Open Source as Business Strategy, Elsevier.

- Henkel, JoAchim (2006)m,"The Jukebox Mode of Innovation - a Model of Commercial Open Source Development", DRUID Working Paper, University of Munich, br. o6 - 25.

- Konjević, Zora (2009) „Istraživanje Stanje i primena informaciono-komunikacionih tehnologija (IKT) u organima lokalne samouprave u AP Vojvodina", Uprava za zajedničke poslove pokrajinskih organa, <http://www.uprava.vojvodina.gov.rs/it_skupovi/ EXCHANGE_3/anketa-Zaric.pdf>, (22. II. 2014).

- „Open Source Strategy in the European Commission“, (2000) European Commision, <http://ec.europa.eu/dgs/informatics/oss_ tech/index_en.htm>, (12. II. 2020.).

- Open Source Observatory, (2010) <,https://joinup.ec.europa.eu/ collection/open-source-observatory-osor>, (20. IV. 2020.).

- „Open Source Observatory Annual Report" (2016) <https://joinup.ec.europa.eu/sites/default/files/document/2017-01/open_source_observatory_annual_report_3.pdf $>$, (20. IV. 2020.).

- Peeling, Nic - Satchell, Julian (2001) „Analysis of the Impact of Open Source Software", Qinetiq, <http://citeseerx.ist.psu.edu/ viewdoc $/$ download?doi=10.1.1.115.8510\&rep=rep1\&type $=$ pdf $>$, (23. II. 202O.).

- Porubović-Vidović, Olivera (2013) „Komercijalni softver ima alternativu“, Tehnični in vsebinski problemi klasičnega in elektronskega arhiviranja, Pokrajinski arhiv Maribor, Radenci, str. 507. 518. 
- Rossi, Bruno i dr. (2006)„A Study on the Introduction of Open Source softver in the Public Administration", The Second International Conference on Open Source Systems (OSS20o6), Como, Italy, <http://www.academia.edu/2752053/A_study_on_the_introduction_of_Open_Source_softver_in_the_Public_Administration>, (28. VIII. 2014.).

- Quiroz Canlas, Ferddie (2019) „Issues and Challenges of Free and Open Source Software Adoption in the Philippines: ABaseline Survey for Information Technology Strategy Formulation", The 4th International Conference on Organization and Management, Abu Dhabi. United Arab Emirates.

- „Usage du logiciel libre dans l'administration“ (2012) Secretariat General Du Gouvernement, <http://circulaire.legifrance.gouv.fr/ pdf/2012/o9/cir_35837.pdf> ( 22. II. 2020.).

- Varian, Hal R. - Shapiro, Carl (2003) „Linux Adoption in the Public Sector: An Economic Analysis“, Berkeley School of Information, University of California, Berkeley, <http://people.ischool.berkeley.edu/ hal/Papers/2004/linux-adoption-in-the-public-sector.pdf $>$, (20.12. 2019.). 
Original scientific paper

Received on October 9, 2019

Mario Pezer - Marko Odak

Mostar - University of Mostar, Faculty of Humanities and Social

Sciences

\section{OPEN SOURCE SOFTWARE IN THE PUBLIC ADMINISTRATION OF BOSNIA AND HERZEGOVINA}

\section{Abstract}

There are many proved advantages and benefits of Free/Libre Open Source Software (FLOSS): better security and reliability, avoiding lock in effect, control over handling sensitive data etc. That is a reason why EU tries to encourage the FLOSS usage in its administration and FLOSS has become very popular in public sector of EU countries in the last fifteen years. Despite that FLOSS usage in South East Europe is almost nonexistent. The focus of this paper is put on the FLOSS usage in the public administration of Bosnia and Herzegovina and on the FLOSS presence compared to proprietary software in the information system of cities and municipalities in Bosnia and Herzegovina. Furthermore, the paper also presents a guideline for possible migration to FLOSS and discusses the major benefits of adopting FLOSS products within the Bosnia and Herzegovina public administration.

Keywords: Open Source Software; public administration; benefits; migration; information science 